Çocuklarda çürük dişlerin bir renkli kompomer ile restore edilmesinden sonra tükürükteki oksidatif stres ve antioksidan seviyelerde meydana gelen değişikliklerin değerlendirilmesi

\section{Evaluation of changes in salivary oxidative stress and antioxidant levels after restored with a color compomer of caries teeth in children}

\section{Prof. Dr. Çiğdem GÜLER}

Ordu Üniversitesi, Diş Hekimliği Fakültesi,

Pedodonti AD, Ordu

Orcid ID: 0000-0002-2581-9050

Prof. Dr. Aysun BAY KARABULUT

Malatya Turgut Özal Üniversitesi, Tıp Fakültesi, Tibbi Biyokimya AD, Malatya

Orcid ID: 0000-0002-7873-2805

Dr. Veli Alper GÖRGEN

Özel Muayenehane, Malatya

Orcid ID: 0000-0002-1861-9456

Dr. Dilek GÜNEŞ

Ankara Il Sağlık Müdürlüğü,

Sincan Ağız ve Diş Sağlığı Merkezi, Ankara

Orcid ID: 0000-0003-4661-6436

Geliş tarihi: 14 Ekim 2019

Kabul tarihi: 19 Eylül 2020

doi:10.5505/yeditepe.2021.19870

\section{Yazışma adresi:}

Doç. Dr. Çiğdem GÜLER

Ordu Üniversitesi, Diş Hekimliği Fakültesi,

Pedodonti Anabilim Dalı, 52100 Ordu

Tel: +90 4522121286

E-posta: cigdem_zehir@yahoo.com
ÖZET

Amaç: Bu çalışmanın amacı, çocuklarda çürük dişlerin bir renkli kompomer ile restore edilmesinden sonra tükürükteki oksidatif stres ve antioksidan seviyelerde meydana gelen değişikliklerin değerlendirilmesidir.

Gereç ve Yöntem: Çalışma yaşları 8-12 yıl (ortalama 8,9 91,3 yıl) arasında değişen 40 çocuk (20 erkek, 20 kız) üzerinde yürütülmüştür. Çalışmada kontrol grupları (çürüksüz kız ve çürüksüz erkek) ve çalışma grupları (çürüklü kız ve çürüklü erkek) oluşturulmuştur ( $n=10$ ). Çürük dişler bir renkli kompomer materyali ile restore edilmiştir. Restorasyonların değerlendirilmesinde Modifiye Ryge kriterleri (USPHS kriterleri) kullanılmıştır. Tükürük total antioksidan seviyesi (TAS), total oksidan seviyesi (TOS) ve 8-Hidroksi-2'-deoksiguanizin seviyesi (8OHdG) üç farklı zamanda [tedavi öncesi (T1), tedavi sonrası 1 ay (T2) ve 3 ay (T3)] değerlendirilmiştir. Tüm veriler istatistiksel olarak analiz edilmiştir.

Bulgular: Tüm renkli kompomerler 1 ve 3 ay kontrollerinde USPHS kriterleri açısından Alpha skoru sergilemiştir. Kontrol gruplarında tükürük TOS, TAS ve 8-OHdG değerleri erkeklerde kızlardan daha yüksek bulunsa bile, farklılık istatistiksel olarak anlamsız bulunmuştur ( $p>0,05)$. Çürük varlığında tüm parametrelerde artış tespit edilmiştir. Çalışma gruplarında tükürük TOS, TAS ve 8-OHdG değerlerinde meydana gelen değişim istatistiksel olarak anlamlı bulunmuştur $(p<0,05)$.

Sonuç: Tükürük TOS, TAS ve 8-OHdG değerleri çürük varlığında artmıştır. Çürük dişlerin renkli kompomer ile restorasyonundan sonra bile parametreler yüksek bulunmuştur.

Anahtar kelimeler: Çürük, renkli kompomer, tükürük, total antioksidan seviyesi (TAS), total oksidan seviyesi (TOS), 8-Hidroksi-2'-deoksiguanizin (8-OHdG).

SUMMARY

Aim: The aim of this study is to evaluate of changes in salivary oxidative stress and antioxidant levels after restored with a colored compomer of caries teeth in children.

Materials and Methods: The study included 40 patients (20 girls and 20 boys), whose age range was 8 to 12 years (average was $10.9 \pm 1.3$ years). Control groups (caries free girls and boys) and experimental groups (caries active girls and boys) were created $(n=10)$. Caries active teeth were restored with a colored compomer material. Modifiye Ryge criteria (USPHS criteria) were used in the evaluation of restorations. The salivary levels of TOS, TAS, and 8-OHdG were determined three different times, as follows: before treatment (T1) and at 1 month (T2) and 3 months (T3) after treatment. All data were statistically analyzed.

Results: All colored compomers displayed an Alpha score in terms of USPHS criteria at 1 and 3 month. Even though the salivary TOS, TAS and 8-OHDG values in the control groups were higher in boys than girls, no statistically significant difference was found $(p>0.05)$. All parameters were increased with caries activity. The statistically significant difference was found changes in salivary TOS, TAS and 8-OHDG values in 
the experimental groups $(\mathrm{p}<0.05)$

Conclusion: Salivary TOS, TAS and 8-OHDG values were increased with caries activity. Even after restoration of the caries with colored compomer, the parameters were determined to be high.

Keywords: Caries, colored compomer, saliva, total antioxidant status (TAS), total oxidant status (TOS), 8-Hydroxy-2'-deoxyguanosine.

\section{GiRiş}

Serbest radikaller bazı etkenler ile (ultraviole ışık, radyasyon, enfeksiyon, enflamasyon ve ilaçlar gibi) oluşabilmektedir. Serbest radikaller savunma sistemi kapasitesini aşabilir veya antioksidan savunma sisteminde bir bozulma meydana gelebilir. Bu durumda hücreyi ve organizmayı etkileyen patolojik bir süreç başlar. ${ }^{1}$ Serbest radikallerin sitotoksik etkileri pekçok süreçte (ateroskleroz, diabet, enflamatuar, enfeksiyöz veya nörolojik hastalıklar, kanser ve yaşlanma gibi) karşımıza çıkarlar. ${ }^{2-4}$ Serbest radikallerin oluşumunu ve bunların meydana getirdiği hasarı sınırlandırmak için antioksidan savunma sistemleri biyolojik sistemlerde gelişmiş̧tir. ${ }^{4,5}$

Diş çürüğü, dişlerin deminerilizasyonu ile başlayarak önce mikroskobik daha sonra da makroskobik olarak sürekli büyüyerek diște kavitasyonlara neden olan bakteriyel, enfeksiyöz ve multifaktöriyel bir hastalıktır. ${ }^{6}$ Şayet yeterli miktarda mikroorganizma herhangi bir enfeksiyöz hastalığı başlatırsa buna cevap olarak ağız içi savunma sistemleri bu enfeksiyöz süreci ortadan kaldırmak veya azaltmak için devreye girer. Tükürük, oksidatif strese karşı ilk savunma basamağıdır? Aktif çürüklü ve çürüksüz çocuk hastalarda, çürük ve tükürük proteinleri veya tükürük antioksidanları arasındaki ilişki değerlendirilmiștir. ${ }^{8-12} \mathrm{An}$ cak bu çalışmalarda hastaların sadece başlangıç tükürük örnekleri değerlendirilmiş, takip periyodu uygulanmamış, ilgili çürük dişlerin restorasyonu ile ilgili bilgi verilmemiştir. 2003 yılından bu yana çocuk hastaların dikkatini çekmek için renkli kompomer materyalleri kullanılmaktadır. MagicFil (Zenith / DMG, Englewood, NJ) piyasaya sunulan ilk renkli kompomerdir. Bu malzeme, çift kürlü sertleşme mekanizması ile dört renkte (mavi, mor, sarı ve evrensel) üretilmiştir. Twinky Star (Voco, Cuxhaven, Almanya) başka bir renkli-kompomer markasıdır ve sekiz farklı renkte üretilmiştir (dut, limon, yeşil, gümüş, mavi, pembe, altın ve turuncu). Twinky Star sadece fotopolimerizasyon ile sertleşir. Bu materyalin formülasyonu, renkli pigmentlerin ve parıltılı parçacıkların varlığı dışında geleneksel komomerlerin formülasyonu ile aynıdır. ${ }^{13,14}$ Renkli kompomerlerin özellikle genç hastalar için motivasyon aracı olabileceği bildirilmiştir. ${ }^{15}$ Bir restorasyonun rengini seçmelerine izin vermek, çocuk hastalara dolgu yapma prosedürüne katılma ve tedavinin etkinliğini artırma fırsatı verir. ${ }^{15}$ Geleneksel ve renkli kompomerlerin kullanılarak termal iletkenlik özelliklerinin değerlendirildiği bir çalışmada, renkli kompomerlerin termal iletkenlik katsayılarının farklı olduğu, özellikle derin kavitelerde gümüş renk kompomerin kullanımından kaçınmak gerektiğini bildirilmiştir. ${ }^{16}$ Yapılan literatür taramasında renkli kompomerlerin kullanımından sonra çocuklarda tükürük oksidatif stres ve antioksidan seviyelerde meydana gelen değişikliklerin değerlendirildiği bir çalışmaya rastlanmamıştır.

Bu çalışmada, karışık dişlenme dönemindeki çürüklü ve çürüksüz kız ve erkek çocuklarda total antioksidan seviyesi (TAS), total oksidatif stres (TOS), oksidatif DNA hasarının göstergesi olan 8-Hidroksi Deoksiguanozin (8OHdG) seviyelerinde meydana gelen değişikliklerin incelenmesi, çürük dişlerin uygulanan bir renkli kompomer restoratif materyali ile restorasyonundan sonra bu değerlerde meydana gelen değişimlerin zamana bağlı olarak karşılaştırılması ve değerlendirilmesi amaçlanmıştır.

\section{GEREÇ VE YÖNTEM}

Bu çalışma, randomize (şansa bağlı rastgele) ve körlenmemiş (non-blinded) bir klinik çalışmadır. Çalışma, TC Inönü Üniversitesi Diş Hekimliği Fakültesi Pedodonti Anabilim Dalı Kliniği'ne başvuran yaşları 8-12 yıl (ortalama 8,9 $\pm 1,3$ yıl) arasında değişen 40 çocuk (20 erkek, 20 kız) üzerinde yürütülmüştür. Çalışmada örneklem boyutunun planlanması için MINITAB sürüm 14.1 yazııım (Minitab Inc, State College, Pa) ile Power analizi yapılmış ve 10 katılımcıdan oluşan bir örneklemin, çalışılan tükürük değişkenlerindeki değişiklikleri ayırt etmek için yeterli istatistiksel gücü sağlayacağı tespit edilmiştir. Çalışmada kontrol grupları (çürüksüz kız ve çürüksüz erkek) ve çalışma grupları (çürüklü kız ve çürüklü erkek) oluşturulmuştur ( $n=10)$. Çürük süt dişlerinin restorasyonu için restoratif materyal olarak bir renkli kompomer (Twinky Star; VOCO, Cuxhaven/ Germany) materyali kullanılmış, tüm restorasyonlar üretici firmanın önerileri doğrultusunda yapılmıştır. Restoratif materyalin rengi (gümüş, altın, portakal, dut, yeşil, limon, mavi, pembe) çocukların seçimi ve ebeveynlerinin onayı doğrultusunda yapılmıştır. Çalışma için, TC İnönü Üniversitesi Tıp Fakültesi İnsan Etik Kurulu'ndan etik kurul onayı alınmıştır (2010-62). Ayrıca, tedavi öncesinde hasta ve ebeveynler yapılacak tedaviler hakkında bilgilendirilmiş ve ebeveynlerinden tedavi uygulamaları ve radyografik değerlendirmeler için bilgilendirilmiş onam alınmıştır.

\section{Katıımcıların Dâhil Edilme Veya Hariç Tutulma Kriterleri}

1- Sistemik bir rahatsızlığa sahip olmaması,

2- Son zamanlarda herhangi bir dehidratasyona neden olabilecek enfeksiyona maruz kalmamış olması,

3- Son 3 ay içerisinde herhangi bir ilaç kullanmamış olma$\mathrm{SI}$,

4- Bilinen veya şüpheli bir alerji hikâyesinin olmaması,

5- Frankl davranış skalasına ${ }^{17}$ göre 3 veya 4 skoru sergilemesi 


\section{Dişlerin Dâhil Edilme Ve Hariç Tutulma Kriterleri}

Dişlerin seçiminde klinik olarak;

1- EBir dişinen fazla iki yüzeyini içine alan çürük mevcudiyetine sahip olmasına,

2- Herhangi bir hipoplazik defekt olmamasına,

3- Dişte grimsi veya pembemsi renk değişimi not edilmemesine,

4- Dişte fark edilebilir çatlak olmamasına,

5- Daimi dişlerinde herhangi bir çürük mevcudiyetinin olmamasına dikkat edilmiştir.

\section{Dişlerin seçiminde radyografik olarak ise;}

1- Dişlerdeki çürük seviyelerinin pulpa ile olan ilişkileri, furkal sahalarında herhangi bir radyolusentliğin olmama$\mathrm{Sl}$,

2- Ekstrand ve ark. ${ }^{18}$ çürük tespitinde kullandıkları skorlamaya göre 2 ve 3 skoruna sahip olması,

3- Lamina dura ve periodontal aralığın normal olarak izlenebilmesi,

4- Patolojik eksternal veya internal rezorpsiyonların olmamasına dikkat edilmiştir.

Kontrol ve Çalışma Gruplarından Başlangıç Tükürük Örneklerinin Alınması

Tükürük örnekleri belirli bir standardizasyon oluşturmak için sabah saatlerinde ve aç karnına alınmıştır. Tüm katııımcıların ağızları öncelikle distile su ile çalkalatıımış ve 5 dakika beklendikten sonra uyarılmamış tükürük örnekleri alınmıştır. Toplanan tükürük örnekleri derhal -80 oC'de derin dondurucuda analiz yapılıncaya kadar saklanmıştır. Kontrol Ve Çalışma Gruplarının 1 ve 3 Ay Sonraki Klinik

\section{Kontrolleri ve Tükürük Örneklerinin Alınması}

Restorasyonların değerlendirilmesinde Ryge kriterleri19 (USPHS kriterleri) kullanılmıştır. Tüm kriterler için Alpha (A) skoru; en yüksek klinik kabul edilebilirlik derecesini ifade ederken, Bravo (B) ve Charlie (C) skorları klinik kabul edilebilirliğin azaldığını göstermektedir.

\section{Tükürük Analizleri}

Total antioksidan seviyesi (TAS), total oksidan seviyesi (TOS), oksidatif DNA hasarının göstergesi olan 8-Hidroksi 2 deoksiguanizin'in (8OHdG) analizleri İnönü Üniversitesi Turgut Özal Tıp Merkezi Biyokimya Laboratuarı'nda yapılmıştır. Tükürük örneklerinde TAS, TOS ve $80 \mathrm{HdG}$ değerlendirmeleri Güler ve ark. ${ }^{20}$ çalışması dikkate alınarak farklı zaman periyodlarında gerçekleştirilmiştir. Restoratif tedavi yapılmadan önce başlangıç değerleri T1, restoratif tedaviden 1 ay sonrası T2 ve restoratif tedaviden 3 ay sonrası T3 olarak isimlendirilmiştir.

\section{Istatistiksel Analizler}

Tüm istatistiksel işlemler SPSS 16.0 for Windows (SPSS Inc., Chicago, IL, USA) paket programı kullanılarak yapılmıştır. $p<0,05$ değerleri istatistiksel olarak anlamlı kabul edilmiştir.

Sonuçlar ortalama \pm standart sapma (SD) olarak ifade edildi. Grup içinde zaman periyodlarına göre TAS, TOS ve
8-OHdG'in değerlerindeki farklıığın değerlendirilmesinde tekrarlı ölçümler varyans analizi kullanıldı (RANOVA), farklııı̆ın olması durumunda ise; kaynağının tespiti için Bonferroni çoklu karşılaştırma testi kullanıldı. Gruplar arasında aynı zaman periyodu içinde TAS, TOS ve 8-OHdG değerlerinin cinsiyet ve çürük varlığı kriterlerine göre dağılımının istatistiksel değerlendirilmesinde ise t testi kullanıldı.

\section{BULGULAR}

Tüm renkli kompomerler 1 ay ve 3 ay kontrollerinde Modifiye Ryge'nin Kriterleri (USPHS kriterleri) dikkate alınarak değerlendirildiğinde; renk uyumu, kavo-surface renk değişikliği, anatomik form, kenar bütünlüğü ve çürük oluşumu açısından Alpha skoru sergilemiştir.

Gruplar içinde farklı zamanlarda [başlangıç (T1), 1 ay (T2) ve 3 ay(T3)] TOS değerlerinin dağılımı Tablo 1'de, TAS değerlerinin dağılımı Tablo 2'de ve 8-OHdG değerlerinin dağılımı Tablo 3'de gösterilmiştir.

Tablo 1. Grup içinde farklı zamanlarda TOS değerlerinin karşılaştırııması.

\begin{tabular}{|c|c|c|c|c|c|c|c|}
\hline \multirow[t]{3}{*}{ Gruplat } & \multicolumn{3}{|c|}{$\begin{array}{c}\text { TOS } \\
\text { ( } \mu \text { mol H202 EquiviL) }\end{array}$} & \multirow[t]{3}{*}{ RANOVA } & \multicolumn{3}{|c|}{ Bonferroni } \\
\hline & $\mathrm{T}_{1}$ & $\mathrm{~T}_{3}$ & $\mathrm{~T}_{3}$ & & $T_{1}-T_{7}$ & $T_{1}-T_{3}$ & $\mathrm{~T}_{2-} \mathrm{T}$, \\
\hline & Onalama $\leq \mathrm{SD}$ & Oralama $\mathrm{SD}$ & Ortalama $=$ SD & & & & \\
\hline Çariksuzk kiz & $6,55 \pm 2,83^{\circ}$ & $6,90 \pm 2,03^{2}$ & $6,70 \pm 1,65^{m}$ & & & & \\
\hline Çaruksaz erkek & $8,11 \pm 2,61^{=}$ & $8,04+2,00^{n}$ & $7,94 \pm 2,23^{x}$ & & & & \\
\hline Caruklu kaz & $8,27 \pm 4,17^{\circ}$ & $17,63 \pm 6,68^{b}$ & $28,74 \pm 10,82^{\circ}$ & 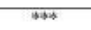 & siso & we. & \$4 \\
\hline Cưruiklū erkek & $8.69 \pm 4.56^{\circ}$ & $22.61 \pm 6.06^{6}$ & $43.29 \pm 21.93^{b}$ & W** & 898 & $\approx *$ & 8 \\
\hline \multicolumn{8}{|c|}{ 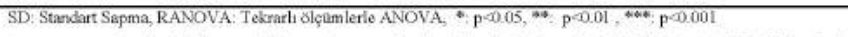 } \\
\hline \multicolumn{8}{|c|}{ 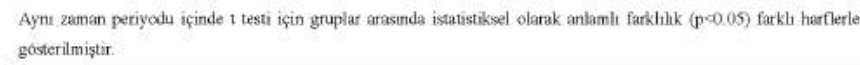 } \\
\hline
\end{tabular}

Tablo 2. Grup içinde farklı zamanlarda TAS değerlerinin karşılaştırılması.

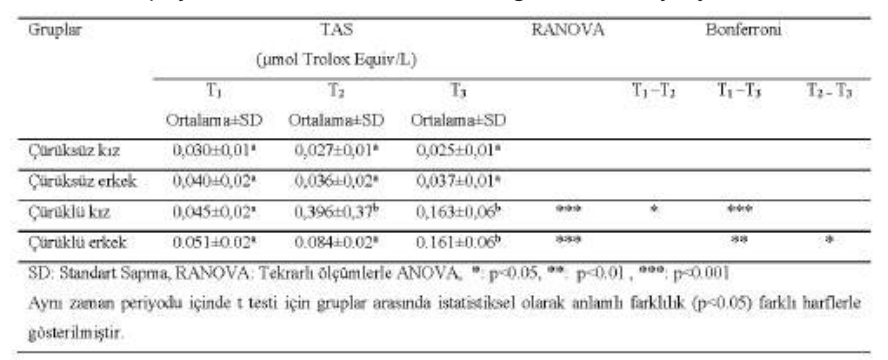

Tablo 3. Grup içinde farklı zamanlarda 8-OHdG değerlerinin karşılaştırılması.

\begin{tabular}{|c|c|c|c|c|c|c|}
\hline \multirow[t]{3}{*}{ Groups } & \multicolumn{3}{|c|}{ 8-OHdG (umol Trolox Equiv L) } & \multirow[t]{3}{*}{ RANOVA } & \multicolumn{2}{|l|}{ Bonferron: } \\
\hline & $T_{1}$ & $\mathrm{~T}_{2}$ & $\mathrm{~T}_{3}$ & & $T_{1}-T_{3}$ & $\mathrm{~T}_{2}-\mathrm{T}_{3}$ \\
\hline & Oralama $=\mathrm{SD}$ & Otalama $=\mathrm{SD}$ & Ortalama $=S \mathrm{SD}$ & & & \\
\hline Çuruksuzkız & $31.56 \pm 9,63^{*}$ & $30,70 \pm 7,47^{4}$ & $30,51 \pm 7.79^{9}$ & & & \\
\hline Çuruksuz erkek & $47,62+22,02^{\text {" }}$ & $46,39 \pm 20,6)^{2}$ & $47,31 \pm 19,36^{2}$ & & & \\
\hline Çüruklu kız & $61,17 \pm 51,89^{\circ}$ & $44,07 \pm 32,54$ & $96,52 \pm 60,94^{\circ}$ & & & \\
\hline Çurukdo enkek & $92,65+63,09^{6}$ & $32,79+16,32^{2}$ & $40,90+20,32^{2}$ & - & " & \\
\hline \multicolumn{7}{|c|}{ 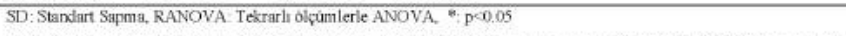 } \\
\hline \multicolumn{7}{|c|}{ 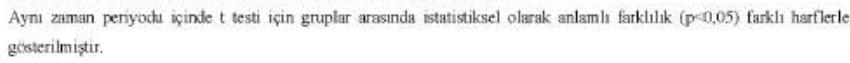 } \\
\hline
\end{tabular}

TOS, TAS ve $80 \mathrm{HdG}$ değerlerinin kontrol gruplarında (çürüksüz kız ve çürüksüz erkek) zamana bağlı olarak verilerin değişimi istatistiksel olarak anlamsız bulunmuştur $(p>0,05)$. Çürüklü kız ve çürüklü erkek gruplarında ise çürük dişlerin tedavi edilmesinden sonra TOS, TAS ve 8-OHdG değerlerin hepsinde zamana bağlı olarak meydana gelen değişim istatistiksel olarak anlamlı bulunmuştur $(p<0,05)$. 
Kontrol grubu olan çürüksüz kız ve çürüksüz erkeklerde TOS, TAS ve 8-OHdG değerleri erkeklerde daha yüksek bulunsa bile farklıık istatistiksel olarak anlamsız bulunmuştur. Değerlendirilen parametreler üzerine cinsiyetin etkisi yoktur. Ancak çürük varlığında tüm değerlendirme parametrelerinde artış tespit edilmiştir. Çürük dişlerin restorasyonundan sonra 1 ay ve 3 aylık kontrollerde bile parametreler yüksek tespit edilmiştir.

\section{TARTIȘMA}

Antioksidanlar diyetimizin önemli bir kısmını oluşturur ve bunlar intrasellüler antioksidanlar ve enzimatik sistemler ile beraber çeşitli enflamasyonlar, enfeksiyonlar veya tümöral oluşumları engelleyebilirler. ${ }^{21}$ Ağız içindeki özellikle periodontal hastalıklar gibi bazı enflamasyonlar ağız içindeki oksidatif hasarın artışı ve antioksidanlardaki azalma ile ilişkilendirilmiştir. ${ }^{3}$

Yapılan literatür incelemesinde çürük ve TAS seviyelerinin değerlendirildiği birkaç çalışma tespit edilmiştir. Tulunoğlu ve ark. ${ }^{8}$ aktif çürüğe sahip çocuklarda total protein ve TAS değerlerinin yüksek olduğunu rapor etmiştir. Kumar ve ark. ${ }^{9}$ çürüksüz ve erken çocukluk çağı çürüğüne sahip olan çocuklarda uyarılmamış tükürükteki total antioksidan kapasitesini (TAC) araştırdıkları çalışmalarında; TAC ve yaş arasında anlamsız, TAC ve dmft skorları arasında ise anlamlı bir korelasyon olduğunu rapor etmişlerdir. Hegde ve ark. ${ }^{10}$ 6-12 yaş arası rampant çürüklü çocuklarda ve çürüksüz çocuklarda TAC değerlerini karşılaştırmışlar; çürüklü çocuklarda TAC seviyesinin arttığını ve TAC'ın çocukların yaşı ile ilişkili olduğunu belirtmişlerdir. Preethi ve ark..$^{11}$ ve Dodwad ve ark..$^{12}$ 7-10 ve 11-14 yaş grubu aktif çürüklü ve çürüksüz çocuklarda TAC değerlerinin araştırıldığı çalışmalarında; çürük varlığında TAC değerlerinin artığını rapor etmişlerdir. Çalışmamızın bulguları da benzer şekilde çalışma ve kontrol grupları arasında ve çalışma gruplarında ise tedavi öncesi ve sonrası arasında anlamlı farklılık ortaya koymuştur. Bir başka deyişle, çürük varlığında TAS değerlerinde artış tespit edilmiştir. Ayrıca, diş çürüğü bulunmayan veya dental restoratif uygulamaları takiben çürüksüz duruma getirilen bireylerde TOS, TAS ve 8-OHdG seviyeleri anlamlı farklıık oluşturmuştur. Ancak oluşan farklılık, 3 aylık takip periyodunda dahi başlangıç seviyelerinden daha yüksek bulunmuştur. Bu duruma karışık dişlenme periyodunun katkısı olmuş olabilir.

Uberos ve ark. ${ }^{22}$ yaptıkları çalışmada süt ve daimi dişlenme dönemindeki çürüksüz çocuklarda, çürüklü çocuklara göre daha düşük total antioksidan kapasitesi (TAC) tespit etmişler, ancak bunun istatistiksel olarak anlamsız olduğunu rapor etmişlerdir. Krawczyk ve ark. ${ }^{23}$ yaptıkları bir çalışmada; 16-23 yaş arası dental çürüksüz hastalarda TAS değerlerinin yüksek olduğunu, TAS değerlerinin çürük veya oral hijyen durumundan etkilenmediğini ve yaş ile arttığını belirtmişlerdir. Çalışmamızın sonuçları bu yazarların bulguları ile uyumlu değildir. Bu uyumsuzluğa, çalışmamızda farklı yaş gruplarından hastaların değerlendirilmesi katkıda bulunmuş olabilir.

Oksidatif stres doğrudan veya dolaylı olarak hücre hasarı ile sonuçlanan, serbest radikal üretimi ile organizmanın antioksidan savunma mekanizması arasındaki dengesizlik olarak tanımlanabilir. Oksidatif stresin pek çok enflamatuar hastalığın (diyabet, ateroskleroz, hipertansiyon ve obezite gibi) ve kanserin patogenezinde rol aldığı bilinmektedir. ${ }^{24,25}$ Serbest radikallerin oluşumunu ve bunların meydana getirdiği hasarı önlemek için, organizmada antioksidan savunma sistemleri geliştirilmiştir. Eğer dokuların antioksidan kapasitesi aşılırsa serbest radikaller hızlı bir şekilde hücresel kompanentlerle reaksiyona girer ve hücrelerin lipid, protein, DNA, karbonhidrat gibi tüm önemli bileşenlerine etki ederek yapılarının bozulmasına neden olurlar. Çürük bakteriyel, enfeksiyöz ve multifaktöriyel bir hastalık olduğu için oksidatif streslerin artışına, bu artışın düzeltilebilmesi amacıyla antioksidan seviyesinde yükselmelere neden olabilir. Yapılan çalışmalarda çürük varlığında tükürük antioksidan seviyesinin artış gösterdiği tespit edilmiştir. ${ }^{8-12}$ Tóthová ve ark. ${ }^{26}$ yaptıkları bir çalışmada çocuklarda tükürük oksidatif stres markırlarının oral hijyen ve periodontal durum ile ilişkili olduğunu rapor etmiştir. Çalışmamızda da benzer şekilde çürüklü kız ve çürüklü erkek gruplarında kontrol gruplarına göre daha yüksek oksidatif stres ve antioksidan seviyeleri tespit edilmiştir. Çürük dişlerin restorasyonundan sonra 1 ay ve 3 aylık kontrollerde bile TOS ve TAS değerleri kontrol gruplarından yüksek tespit edilmiştir.

8-OHdG vücuttaki oksidatif DNA yıkımını değerlendirmek için kullanılabilir. Bu markırın tespit edilmesi ile oksidatif stres yoluyla sitotoksisitenin kanıtlanması mümkündür ve bu nedenle kronik enflamatuar hastalıklarda 8-OHdG oksidatif yıkımın biyomarkırı olarak kabul edilmektedir. Schulpis ve ark. ${ }^{27}$ valproik asit tedavisi gören çocuklarda serum TOS ve 8-OHdG seviyelerini değerlendirmişler, karaciğer hücrelerinde DNA hasarının göstergesi olarak 8-OHdG değerlerinin kontrol grubuna göre daha yüksek olduğunu ve bu markııın güvenilir sonuçlar sergilediğini rapor etmişlerdir. Tükürükte $8-\mathrm{OHdG}$, birkaç çalışmada periodontal hastalıkların değerlendirilmesinde bir markır olarak kullanıımış, periodontitis varlığında $8-\mathrm{OHdG}$ seviyesinde artış tespit edildiği bildirilmiştir. ${ }^{28-30}$ Çalışmamızda da benzer şekilde çürük varlığında 8-OHdG seviyesinde artış varken, dişlerin tedavisini takiben azalma elde edilmiştir.

Diş hekimliğinde kullanılan materyallerin klinik başarısı sadece mekanik ve estetik özellikleri açısından değil, aynı zamanda biyolojik açıdan güvenilirliği ve dokulara uyumluluğuna bakılarak değerlendirilmelidir. Rezin esaslı monomerler kompleks yapıdaki hücresel iletişimi ve sinyal iletim yollarını çevresel stres kaynağı meydana getirerek 
bozmaktadır. ${ }^{31}$ Normal şartlarda hücrede oksidatif stres oluşturan reaktif oksijen türleri ile bunların yok edilmesinden ve kontrolünden sorumlu olan antioksidan sistemi arasında bir denge mevcuttur. Fakat rezin içerikli monomerlerin oluşturduğu oksidatif stres hücre içi enzimatik ve enzimatik olmayan antioksidanların kapasitesini aşan reaktif oksijen türlerinin üretimine neden olmaktadır. ${ }^{32} \mathrm{Bu}$ sebeple reaktif oksijen türlerinin üretimi rezin içerikli monomer sitotoksisitesinde hücresel stresin erken belirteçlerinden biri olarak gösterilmektedir. ${ }^{33}$

Rezin esaslı restoratif materyallerin yetersiz polimerizasyonunun, artık monomer olarak adlandırılan aktive edilmemiş serbest monomerlerinin oluşmasına neden olabilmektedir. Artık monomerlerin rezin matriksinden oral kavitedeki sıvılara salınabileceği bilinmektedir. ${ }^{34}$ Rezin matriksin yetersiz polimerizasyonu sonucu açığa çıkan artık monomerlerden Trietilen glikol dimetakrilat (TEGDMA), Bis-fenol A glisidil metakrilat (Bis-GMA), Uretan di metakrilat (UDMA), 2-Hidroksietil metakrilat (HEMA) ve Metil metakrilat (MMA) rapor edilmiştir. Bu artık monomerlerin ağız mukozası tarafından emilebileceği ve sindirim sistemine geçebileceği bildirilmiştir. ${ }^{35}$ TEGDMA ve HEMA gibi monomerlerin, oksidatif stresle bağlantılı olarak sitotoksik etki oluşturduğunu bildiren çalışmalar olmasına rağmen mekanizması henüz tam olarak ortaya konulmamıştır. ${ }^{36} \mathrm{Bu}$ çalışmada çürük dişlerin bir renkli kompomer ile restorasyonundan sonra 1 ay ve 3 aylık kontrollerde bile TOS ve TAS değerleri kontrol gruplarından yüksek tespit edilmiştir. Bu duruma renkli kompomerlerin yetersiz polimerizasyonu ve yetersiz polimerziasyon sonucunda açığa çıkan artık monomer salınımı katkı vermiş olabilir.

Çalışmamızın snırlamaları; ilk olarak çalışma 8-12 yıl (or-

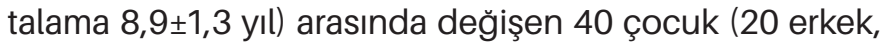
20 kız) üzerinde yürütülmüştür. Tüm hastalar karışık dişlenme periyodundadır. Farklı yaş gruplarında ve farklı dişlenme periyodlarında sonuçlar değişiklik gösterebilir. ìkinci olarak, çalışmamızda restoratif uygulamada sadece bir materyal kullanılmıştır. Farklı restoratif materyaller uygulandığında sonuçlar değişebilir. Bu nedenle bulgularımızın desteklenmesi için örneklem büyüklüğü arttırılarak ilave çalışmalar yapılması önerilmektedir.

\section{SONUÇLAR}

TOS, TAS ve 8-OHdG değerleri çürük varlığında artmıştır. Çürük dişlerin bir renkli kompomer ile restorasyonundan sonra 1 ay ve 3 aylık kontrollerde bile parametreler yüksek tespit edilmiştir. Verilerin başlangıç değerlerine ne zaman yaklaşacağı daha uzun süreli çalışmalar ile değerlendirilmelidir.

\section{TEŞEKKÜR}

Bu çalışma Recep Tayyip Erdoğan Üniversitesi Diş Hekimliği Fakültesi 1. Uluslararası Diş Hekimliği Sempozyumu'nda poster bildiri olarak sunulmuştur. Çalışma için finansal destekte bulunan İnönü Üniversitesi Bilimsel Araştırma
Projeleri Koordinasyon Birimi'ne teşekkür ederiz (Proje No: BAP 2010-143).

\section{KAYNAKLAR}

1- Karabulut H, Gülay MŞ. Serbest radikaller. MAKÜ Sag. Bil. Enst. Derg. 2016,4(1):50-59.

2- Baltacıoglu $E$, Akalın FA, Alver A, Balaban F, Ünsal M ve ark. Total antioxidant capacity and superoxide dismutase activity levels in serum and gingival crevicular fluid in post-menapausal women with chronic periodontitis. $J$ Clin Periodontol 2006; 33: 385-92.

3- Brock GR, Butterworth CJ, Mathews JB, Chapple ILC. Local and systemic total antioxidant capacity in periodontitis and health. J Clin Periodontol 2004; 31: 515-21

4- McCord JM. The evalution of free ardicals and oxidative stres. Am J Med 2000;108: 652-59.

5- Wei PF, Ho KY, Ho YP, Wu YM, Yang YH ve ark. The investigation of glutathione peroxidase, lactoferrin, myeloperoxidase and interleukin 1-beta in gingival crevicular fluid: implications for oxidative stres in human periodontal diseases. J Periodontal Res 2004; 39: 287-93.

6- Çakır FY, Gürgan S, Attar N. Çürük mikrobiyolojisi. Hacettepe Diş Hekimliği Fakültesi Dergisi 2010; 34: 78-91.

7- Çağlayan F, Yılmaz AB. Rekürrent Aftöz Stomatitisli Hastalarda Tükürük Antioksidan Seviyeleri. Atatürk Üniv. Diş Hek. Fak. Derg.2008; 18: 99-104.

8- Tulunoglu O, Demirtas S, Tulunoglu I. Total antioxidant levels of saliva in children related to caries, age, and gender. Int J Paediatr Dent 2006; 16: 186-91.

9- Kumar D, Pandey RK, Agrawal D, Agrawal D. An estimation and evaluation of total antioxidant capacity of saliva in children with severe early childhood caries. Int J Paediatr Dent 2011 Nov; 21(6): 459-64.

10- Hegde AM, Rai K, Padmanabhan V. Total antioxidant capacity of saliva and its relation with early childhood caries and rampant caries. J Clin Pediatr Dent 2009; 33(3): 231-4.

11- Preethi BP, Reshma D, Anand P. Evaluation of Flow Rate, pH, Buffering Capacity, Calcium, Total Proteins and Total Antioxidant Capacity Levels of Saliva in Caries Free and Caries Active Children: An In Vivo Study. Indian J Clin Biochem 2010; 25(4): 425-8.

12- Dodwad R, Betigeri AV, Preeti BP. Estimation of total antioxidant capacity levels in saliva of caries-free and caries-active children. Contemp Clin Dent 2011; 2(1): 17-20.

13- Krämer N, Frankenberger R. Compomers in restorative therapy of children: a literature review. Int $\mathrm{J}$ Paediatr Dent 2007; 17: 2-9.

14- Croll TP, Helpin ML, Donly KJ. Multi-colored dual-cured compomer. Pediatr Dent 2004; 26: 273-6.

15- Schäfer $C$. The use of colored components as fillings in deciduous teeth. Dent Today 2005; 24: 130-2.

16- Guler C, Keles A, Guler MS, Karagoz S, Cora ÖN, 
Keskin G. Thermal conductivity of different colored compomers. J Appl Biomater Funct Mater. 2017 Nov 10;15(4):e362-e368.

17- Wright GZ. Psychologic management of children's behaviors. In: McDonald RE, Avery DR, editors. Dentistry for the child and adolescent. St Louis, Missouri: Mosby; 2000. p. 34-51.

18- Ekstrand KR, Ricketts DN, Kidd EA. Reproducibility and accuracy of three methods for assessment of demineralization depth of the occlusal surface: an in vitro examination. Caries Res 1997; 31: 224-31.

19- Ryge G. Clinical criteria. Int Dent J 1980; 30: 347-58.

20- Guler C, Toy E, Ozturk F, Gunes D, Karabulut AB, Otlu O. Evaluation of salivary total oxidant-antioxidant status and DNA damage of children undergoing fixed orthodontic therapy. Angle Orthod 2015; 85(2): 239-44.

21- Goldie M P. Antioxidants in oral health care: making the connection. Int J Dent Hyg 2005; 3: 93-5.

22- Uberos J, Alarcón JA, Peñalver MA, Molina- Carballo $\mathrm{A}$, Ruiz $\mathrm{M}$ ve ark. Influence of the antioxidant content of saliva on dental caries in an at-risk community. $\mathrm{Br}$ Dent $\mathrm{J}$ 2008; 205(2): E5.

23- Krawczyk D, Sikorska-Jaroszyńska MH, Mielnik-Błaszczak M, Pasternak K, Kapeć E ve ark. Dental caries and total antioxidant status of unstimulated mixed whole saliva in patients aged 16-23 years. Adv Med Sci 2012; 57(1): 163-8.

24- Vishal RT, Sharma S, Mahajan A, Bardi GH. Oxidative Stress: A Novel Strategy in Cancer Treatment. JK Sci 2005; 7: 1-3.

25- Chandra J, Samali A, Orrenius S. Triggering and modulation of apoptosis by oxidative stress. Free Rad Med Biol 2000; 29: 323-33.

26- Tóthová L, Celecová V, Celec P. Salivary markers of oxidative stress and their relation to periodontal and dental status in children. Dis Markers 2013; 34(1): 9-15.

27- Schulpis KH, Lazaropoulou C, Regoutas S, Karikas GA, Margeli A ve ark. Valproic acid monotherapy induces DNA oxidative damage. Toxicology 2006; 217(2-3): 22832.

28- Takane $M$, Sugano $N$, Iwasaki $H$, Iwano $Y$, Shimizu N ve ark. New biomarker evidence of oxidative DNA damage in whole saliva from clinically healthy and periodontally diseased individuals. J Periodontol 2002; 73: 551-4. 29- Ongöz Dede F, Otan Özden F, Avcı B. 8-OHdG Levels in Gingival Crevicular Fluid and Saliva from Patients with Chronic Periodontitis During Initial Periodontal Treatment. J Periodontol 2012;16.

30- Sezer U, Ciçek Y, Canakçi CF. Increased salivary levels of 8-hydroxydeoxyguanosine may be a marker for disease activity for periodontitis. Dis Markers 2012; 32(3): 165-72. 31- Krifka S, Spagnuolo G, Schmalz G, Schweikl H. A review od adaptive mechanisms in cell responses towards oxidative stress caused by dental resin monomers. Biomater 2013; 34: 4555-4563.

32- Schweikl H, Spagnulo G, Schmalz G. Genetic and cellular toxicology of dental resin monomers. J Dent Res 2006; 85(10): 870-877.

33- Engelmann J, Volk J, Leyhausen G, Geurtsen W. ROS formation and glutathione levels in human oral fibroblasts exposed to TEGDMA and camphorquinone. J Biomed Mater Res Part B: Appl Biomater 2005; 75B: 272-6.

34- Spahl W, Budzikiewicz H, Geurtsen W. Determination of leachable components from four commercial dental composites by gas and liquid chromatography/mass spectrometry. J Dent 1998; 26(2): 137-145.

35- Lee DH, Lima BS, Lee YK, Ahn SJ, Yanga HC. Involvement of oxidative stress in mutagenicity and apoptosis caused by dental resin monomers in cell cultures. Dent Mater 2006; 22: 1086-1092.

36- Stanislawski L, Lefeuvre M, Bourd K, Soheili-Majd E, Goldberg $\mathrm{M}$, et al. TEGDMA induced toxicity in human fibroblasts is associated with early and drastic glutathione depletion with subsequent production of oxygen reactive species. J Biomed Mater Res Part A 2003; 66(3): 476-482. 